7. Reprod. Fert. (1975) 45, 69-72

\title{
TEMPORARY STERILITY PRODUCED IN MALE MICE BY 5-THIO-D-GLUCOSE
}

\author{
J. R. ZYSK, A. A. BUSHWAY, R. L. WHISTLER AND W. W. GARLTON* \\ Department of Biochemistry and * Department of Microbiology, \\ School of Veterinary Medicine, Purdue University, Lafayette, Indiana 47907, U.S.A.
}

(Received 10th December 1974)

\begin{abstract}
Summary. When 5-thio-D-glucose was fed to male mice at daily dose levels greater than $30 \mathrm{mg} / \mathrm{kg}$ sperm development was completely inhibited within 3 weeks and remained so without impairment of libido for the experimental period of 7 weeks. Removal of this substance from the diet resulted in a resumption of sperm development and fertility within 5 to 8 weeks. Normal litters were sired by males which had recovered after this treatment.
\end{abstract}

\section{INTRODUCTION}

The compound 5-thio-D-glucose, which is the nearest chemical analogue of biologically important D-glucose, has been shown to have no significant acute toxicity in animals, but competitively to inhibit active transport of $\mathbf{D}$-glucose across cell membranes (Whistler \& Lake, 1972). The compound has an $L_{50}$ of $14 \mathrm{~g} / \mathrm{kg}$ in rats (Whistler \& Hoffman, 1968); it tastes sweet and has a sweetness value approximately that of $D$-glucose. Because of its competitive inhibition to the active transport of $\mathrm{D}$-glucose, it has a pseudodiabetogenic effect in animals when given in large doses, but the effect is short-lived since about $95 \%$ of the analogue is excreted within a period of $6 \mathrm{hr}$ (R. L. Whistler \& M. J. Pitts, unpublished results). At lower doses, normal blood sugar levels are maintained (R. L. Whistler \& M. J. Pitts, unpublished results).

Since there is ample evidence that D-glucose significantly affects sperm development (Davis, 1969), we have undertaken a preliminary examination of the effect on fertility and sperm production in male mice given different dosages of 5-thio-D-glucose mixed into their otherwise normal rations.

\section{MATERIALS AND METHODS}

Adult, male Swiss albino mice which weighed 30 to $40 \mathrm{~g}$ were used as test animals. The animals were housed under conditions of controlled temperature and lighting. A diet of mouse chow was fed freely. The daily food consumption was measured for 1 week so that the correct dose of 5-thio-D-glucose could be administered in the feed. Groups of mice were fed $0,20,25,30,40$ or $100 \mathrm{mg}$ 5-thio-D-glucose $/ \mathrm{kg}$.

At weekly intervals, two mice fed each dose level were killed and the testes and epididymides were removed, weighed and fixed for histological examina- 
tion. When spermatogenesis was totally inhibited, food containing 5-thio-Dglucose was withdrawn from twenty animals in each group and standard chow was then fed. Two of these animals from each group were killed at weekly intervals, their testes and epididymides removed, weighed and examined histologically.

Once spermatogenesis was re-established, four mice from each group were mated with a number of females and the general health of the progeny examined.

Table 1. Effect of oral doses of 5-thio-D-glucose on the relative weight of testes to total body weight in rats*

\begin{tabular}{cccccc}
\hline $\begin{array}{c}\text { Treatment } \\
(\mathrm{mg} / \mathrm{kg})\end{array}$ & 7 days & 21 days & 35 days & 56 days $\dagger$ & 105 days \\
\hline 0 & 100 & 100 & 100 & 100 & 100 \\
20 & -95 & 95 & 71 & 75 & 73 \\
40 & 89 & 67 & 61 & 54 & 75 \\
100 & 115 & 60 & 61 & & \\
\hline
\end{tabular}

* Expressed as testicular weight/body weight using $100 \%$ as the control ratio.

$\dagger$ Administration of 5-thio-D-glucose was discontinued at this time.

\section{RESULTS}

Periodic determination of testis weight and histopathological alterations showed disturbances of spermatogenesis in the mice receiving more than $30 \mathrm{mg} 5$-thioD-glucose $/ \mathrm{kg}$. The time of onset and degree of testicular alteration varied with the daily dose level, but in general was observable microscopically after 14 days. A significant decrease in testicular weight became apparent after 21 days (Table 1). Animals also lost their ability to fertilize females although libido was not impaired.

Testicular changes were related to the dose and duration of feeding. The initial histological change seen in mice either ingesting a high daily dose (100 $\mathrm{mg} / \mathrm{kg}$ for 1 week) or a low daily dose $(20 \mathrm{mg} / \mathrm{kg}$ for 2 weeks) was the presence of a few enlarged spermatogenic cells in the lumen of seminiferous tubules or the spermatid zone of the germinal epithelium (P1. 1, Fig. 1). The hypertrophied cells were characterized by distinctly eosinophilic cytoplasm and dense eosinophilic nuclei. Such cells were also found in the epididymal tubules. Spermatogenesis was active in such testes and spermatozoa were present in the lumina of the tubules of the epididymis.

After 2 weeks on the high dose or 3 to 4 weeks on the low dose, the number of hypertrophied (degenerating) cells increased and the greatest numbers were

\section{EXPLANATION OF PLATE 1}

FIG. 1. Sections of seminiferous tubules from mouse given a daily dose of $20 \mathrm{mg} 5$-thioD-glucose/kg body weight for 2 weeks. Enlarged spermatogenic cells are present near the lumen of the central tubule. $\mathrm{H} \& \mathrm{E}, \times 225$.

FIG. 2. Section of testis from mouse given $100 \mathrm{mg} 5$-thio-D-glucose/ $/ \mathrm{kg}$ daily for 2 weeks. Numerous giant cells are present in the central seminiferous tubules. H \& E, $\times 90$.

FIG. 3. Higher power view of same testis as in Fig. 2, showing giant cells with numerous peripheral or central nuclei. H \& E, $\times 225$.

Fig. 4. Section of testis from mouse given $100 \mathrm{mg} \mathrm{5-thio-D-glucose/kg} \mathrm{daily} \mathrm{for} 8$ weeks. Most tubules are filled with eosinophilic masses of cellular debris. $\mathrm{H} \& \mathbf{E}, \times 90$. 


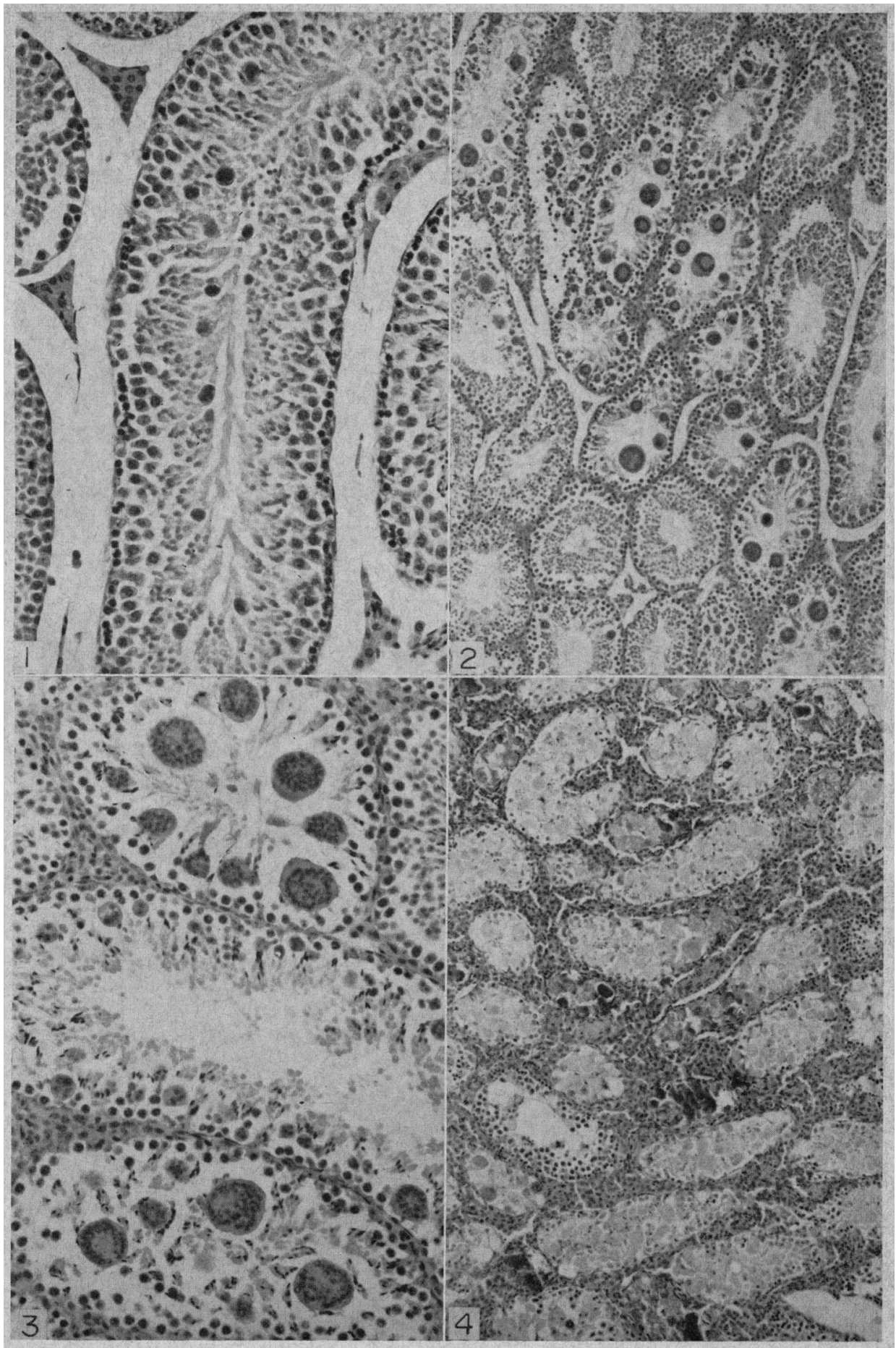

(Facing p. 70) 


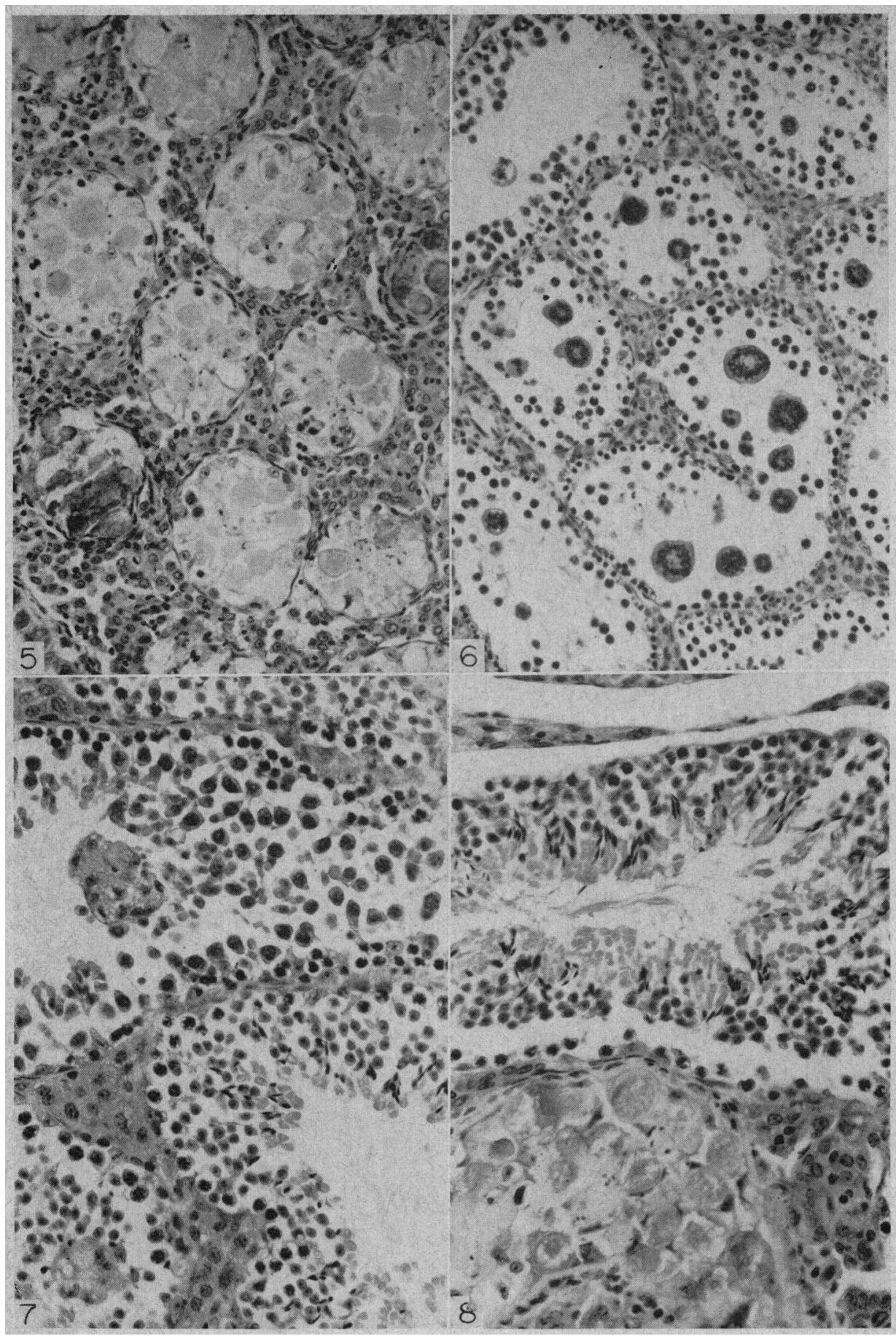

(Facing p. 71) 
found within the lumina of tubules that retained the earlier cell stages of spermatogenesis but few or no spermatids. At this stage of alteration, the hypertrophied cells became degenerate, as indicated by formation of cytoplasmic vacuoles and the irregular contour of the nucleus. Spermatogenesis was still active in most of the tubules and spermatozoa were present in epididymal tubules.

As the testicular changes became more severe, there was a marked reduction in the number of spermatogenic cells and an absence of spermatids and spermatozoa from the tubules of the epididymis.

Giant cells appeared in a number of seminiferous tubules (Pl. 1, Fig. 2). These cells were extremely large with abundant darkly eosinophilic cytoplasm and numerous nuclei arranged either in a wreath-like fashion at the periphery of the cytoplasm or as centrally or eccentrically located masses (Pl. 1, Fig. 3). Some of these cells had undergone necrosis as the nuclei were either pyknotic or had undergone karyorrhexis accompanied by cytolysis (Pl. 1, Fig. 4). As more and more of the syncytial giant cells became necrotic, tubules becoming filled with eosinophilic masses and necrotic giant cells. Some tubules were atrophic and filled with calcified debris (PI. 2, Fig. 5).

The most severely affected testes were extremely small and contained only atrophied tubules that had few or no germinal cells or a few syncytial giant cells but were lined by viable Sertoli cells (PI. 2, Fig. 6).

Normal sperm development was seen in mice 5 to 6 weeks after treatment $(30 \mathrm{mg} / \mathrm{kg}$ ) was discontinued, but 8 weeks were required after higher dose levels $(100 \mathrm{mg} / \mathrm{kg})$, by which time testes weight and appearance was nearly normal (Pl. 2, Figs 7 and 8). Sperm regeneration at 8 weeks was observed at all dose levels. Litters sired by the ten animals tested were normal in size and the general health of both $F_{1}$ and $F_{2}$ progeny was good.

No significant change in body weight of treated males compared to controls was observed until the daily dose exceeded $30 \mathrm{mg} / \mathrm{kg}$. Preliminary studies showed that the average weight difference between four animals treated with 75 or $165 \mathrm{mg} 5$-thio-D-glucose $/ \mathrm{kg}$ and four control animals was $1.5 \mathrm{~g}$ and $3.0 \mathrm{~g}$ respectively after 6 weeks.

\section{DISGUSSION}

It is apparent that 5-thio-D-glucose can produce complete inhibition of sperma-

\section{EXPLANATION OF PLATE 2}

Fig. 5. Section of testis from mouse given $100 \mathrm{mg}$ 5-thio-D-glucose/kg daily for 8 weeks. Small tubules contain either globoid masses of pale eosinophilic cellular debris or calcified debris. $H \& E, \times 225$.

Fic. 6. Section of testis from mouse given $100 \mathrm{mg}$ 5-thio-D-glucose/kg daily for 6 weeks. The seminiferous tubular epithelium is atrophied and the lumen contains only a few small spermatogenic cells and giant cells. H \& E, $\times 225$.

FIG. 7. Photomicrograph of testis from mouse treated with $30 \mathrm{mg} 5$-thio-D-glucose $/ \mathrm{kg}$ body weight daily for 8 weeks and then allowed to recover for 8 weeks. Spermatids are present in two of the three seminiferous tubules illustrated. Syncytial giant cells in the lumen are evidence of prior injury. $\mathrm{H} \& \mathrm{E}, \times 225$.

FIG. 8. Photomicrograph of testis from mouse given $75 \mathrm{mg}$ 5-thio-D-glucose $/ \mathrm{kg}$ body weight daily for 8 weeks and then allowed to recover for 8 weeks. One seminiferous tubule of normal appearance is adjacent to one containing debris of necrotic spermatogenic cells. $\mathbf{H} \& \mathbf{E}, \times 225$. 
togenesis in male mice, even when given at a daily dose level of $30 \mathrm{mg} / \mathrm{kg}$. This is below the dose level required to produce hyperglycaemia.

There is ample evidence that spermatogenesis is particularly sensitive to D-glucose concentrations. Davis (1969) has shown that addition of 0.009 M-Dglucose to incubated sections of rat testes greatly increases amino acid incorporation into protein. Other reports emphasize the importance of D-glucose in maintaining the normal morphological appearance of the rat testis. Thus, experimentally induced hyperglycaemia (Mancini et al., 1960) or alloxan diabetes (Deb \& Chattergee, 1963) results in damage to the seminiferous tubules. Male rats rendered diabetic by pancreatectomy are found to have a decreased fertility (Folgia et al., 1963). Reproductive function in the human male is markedly affected by the diabetic state with its associated presence of hyperglycaemia. Diabetic men have been reported to have an increased incidence of impotence (Schoffling et al., 1963), a decreased sperm count (Babbott et al., 1958), poor sperm motility (Klebanow \& MacCleod, 1960) and atrophic changes in the germinal epithelium of the testes (Babbott $e t$ al., 1958). These data imply that D-glucose is a potent factor in testicular function. Whether 5-thio-D-glucose acts by way of its known inhibitory effect on active transport of D-glucose has not been established.

These preliminary results establish that 5-thio-D-glucose can completely inhibit spermatogenesis and fertility in male mice and that removal of the analogue from the diet allows full recovery of spermatogenesis and fertility. It may therefore be possible to control fertility in male mice by a sugar analogue such as 5-thio-D-glucose without the use of hormones or toxic chemicals.

Work is in progress to investigate the effect of 5-thio-D-glucose on D-glucose and amino acid transport in the testes of rats and its effect on the glycolytic enzymes of this organ.

\section{AGKNOWLEDGMENT}

This work was supported in part by Grant No. AM 15641 from the National Institute of Health.

\section{REFERENCES}

Babbott, D., Rubin, A. \& Ginsburg, S.J. (1958) The reproductive characteristics of diabetic men. Diabetes 7, 33-35.

DAvis, J.R. (1969) Metabolic aspects of spermatogenesis. Biol. Reprod. 1, 93-118.

Deb, C. \& Chattergee, A. (1963) Role of ascorbic acid on testicular degeneration in alloxan diabetic rats. Experientia 19, 595-596.

Folgia, V.G., Borghelli, R.F., Chieri, R.A., Fernandez-Collazo, E.L., Spindler, I. \& Wesely, O. (1963) Sexual disturbances in the diabetic rat. Diabetes 12, 231-237.

KLebanow, D. \& MAcGleOD, J. (1960) Semen quality and certain disturbances of reproduction in diabetic man. Fert. Steril. 11, 255-261.

Mancini, R.E., Penhos, J.C., IzQuirro, I.A. \& Heinrich, J.J. (1960) Effects of acute hypoglycemia on rat testis. Proc. Soc. exp. Biol. Med. 104, 699-702.

Schopfling, I., Federlin, K., Ditschuneit, H. \& Pfeiffer, E.F. (1963) Disorders of sexual function in male diabetics. Diabetes 12, 519-527.

WhistleR, R.L. \& Hoffman, D.J. (1968) Diabetogenic action of 5-thioglucopyranose in rats. Biochemistry, N.Y. 7, 4479-4483.

WHISTLER, R.L. \& LAKE, W.C. (1972) Inhibition of cellular transport processes by 5-thio-D-glucopyranose. Biochem. F. 130, 1-7. 